\title{
The Kingdom of Bhutan: a democracy by obligation
}

\author{
Karim Quintino* \\ * CIEP - Centro de Investigação do Instituto de Estudos Políticos da Universidade Católica, Portugal; \\ karimquintino@hotmail.com
}

\section{Resumo}

A maioria das transições democráticas tem demonstrado como é possível passar de um ponto de partida autoritário para um constante estado de compromisso. O Reino do Butão, um pequeno estado que faz fronteira com a Índia e a China, localizado no interior das Montanhas dos Himalaias, é um exemplo ilustrativo desse paradigma. Não só este país recebeu recentemente amplas práticas democráticas após um século de domínio monárquico, mas, mais interessante, fê-lo por decreto real. Esta inusitada transição de cima para baixo fez com que o monarca dominante efetivamente tivesse "forçado" a democracia sobre as pessoas, em vez do contrário, o que desafiou o paradigma costumeiro da democratização. No entanto, o processo de democratização do Butão foi dificultado numa fase inicial porque a maioria dos cidadãos butaneses permanecia satisfeita com o anterior regime monárquico. Como tal, o propósito do artigo é esclarecer o leitor sobre as características da democracia butanesa e o seu processo precedente de democratização, ao mesmo tempo que fornecendo uma possível resposta sobre se existe um padrão comum no processo de transição do autoritarismo para a democracia. Para isso, o artigo analisa, em primeiro lugar, a história política moderna do Butão; em segundo lugar, examina as idiossincrasias da democracia butanesa; e em terceiro lugar, mostra como os antecedentes históricos, religiosos e sociais do Butão levaram a um processo peculiar de consolidação democrática.

Palavras-chave: Butão; consolidação; democratização; transição

\begin{abstract}
Most democratic transitions have demonstrated how it is possible to move from an authoritarian starting point towards an ongoing state of compromise. The Kingdom of Bhutan, a small state bordering India and China and located deep within the Himalayan Mountains, stands as an illustrative case of that paradigm. Not only has that country recently welcomed extensive democratic practices after a century of monarchical rule, but more interestingly, it did so by royal decree. This unusual top-down transition saw the ruling monarch effectively "enforcing" democracy onto the people rather than the opposite, which defied the customary paradigm of democratisation. Nonetheless, Bhutan's process of democratisation has been hampered at an initial stage because most Bhutanese citizens remained satisfied with the previous monarchical regime. As such, the purpose of the communication is to enlighten the reader with the features of Bhutanese democracy and its preceding process of democratisation, while providing a possible answer on whether there is a common pattern in the transitional process of authoritarianism to democracy. In order to do so, the article firstly looks at Bhutan's modern political history; secondly, it analyses the idiosyncrasies of Bhutanese democracy; and thirdly, it shows how the historical, religious and social background of Bhutan has led to a peculiar process of democratic consolidation.
\end{abstract}

Keywords: Bhutan; consolidation; democratisation; transition 


\section{Introduction}

Globalisation and development are two intrinsically intertwined phenomena. The benefits of conforming to such process - sharing a common market with superpowers, easier access to top-of-the-edge technology, and experience an overall improvement in socio-economic performance, for instance - prove to be too tempting for many developing nations that have nevertheless attempted to resist to its appeals. As more and more of these open up to the rest of the world, with hopes of vindicating on the international stage, the amalgamation of cultural, economic and political Western traits becomes a certitude. Nonetheless, one country that largely stands as an exception to these outcomes is Bhutan. This small South Asian country has recently welcomed extensive democratic practices, but still remains a fairly isolated nation; as a consequence, it has developed its own particularistic version of democracy. As such, the purpose of this paper is to enlighten the reader with the features of Bhutanese democracy and its preceding process of democratisation, while providing a possible answer on whether there is a common pattern in the transitional process of authoritarianism to democracy. In order to do so, this paper is divided in three parts. The first looks at Bhutan's modern political history, while the second looks specifically at the peculiarities of Bhutanese democracy, and at how that system evolved through time. The third and final chapter, which also functions as a general conclusion, argues that due to the historical, religious and social background of this country, the process of democratic consolidation has turned out to be quite distant from other cases.

\section{Bhutan's Modern Political History}

The Kingdom of Bhutan is a small state located deep within the Himalayan Mountains, of approximately the size of Switzerland, and bordering the two most populous countries in the world - India and China. It has a population of 780,250 people in 2016 (Bureau of Bhutan, 2016), and is still largely composed of a rural society, whereby sixty percent $(60 \%)$ of the labour force works in agriculture. In 2014, the GDP per capita was of US\$2,611.74, while the poverty rate stood at 12,0\% (Bureau of Bhutan, 2016). Since the official religion of Bhutan is Buddhism, and given that Bhutanese citizens transpose those religious principles onto practically every sphere of society - from architecture to personal relationships - , tourists tend to perceive this country as the last Shangri-La on Earth. Accordingly, due to its limited accessibility, Bhutan has remained an isolated country for most of its existence. It was not until the 1970s that this nation welcomed its first tourists, and to this day government officials regulate tourism influx: only a certain number of tourists are allowed into Bhutan each year, and there is an established fixed rate that forces foreigners to pay US $\$ 200$ - US $\$ 250$ per day of visit. In several aspects, visiting Bhutan is like travelling back in time: Bhutan's frontiers were more than mere geographical apparatuses; they stood as a way of protecting the Kingdom from external influences. As a result, Bhutan became further isolated from the rest of the world. Things most Westerners often take for granted, such as an Internet connection, televisions, telephones (not to mention mobile phones), and being able to dress as one wishes were prohibited only a couple of decades ago. 
The modern political history of the Kingdom of Bhutan hardly resembles any other in the world. For most of the last century, Bhutan was under the rule of a hereditary absolute monarchy, but became a constitutional monarchy (or in other words, a democracy) at the beginning of the $21^{\text {st }}$ century. What is truly astonishing by this event is the fact that the transition was imposed through royal decree. This rather unusual top-down transition (Muni, 2014) effectively meant that the ruling monarch "enforced" democracy onto the people, rather than the opposite. It all started on December 17, 1907, when the House of Wangchuck was founded, beginning an era of absolute monarchy in Bhutan. The first Kings - also known as Dragon Kings —, were Ugyen Wangchuck, who ruled from 1907 to 1926, and his son Jigme Wangchuck, who ruled from 1926 to 1952. After the second Dragon King passed away in 1952, his son Jigme Dorji Wangchuck succeeded him and became the third Dragon King of Bhutan, who would rule from 1952 until 1972. It was from this period onwards that the political shift towards democracy began.

Let us consider three stages of democratisation in Bhutan. The first took place precisely when Jigme Dorji Wangchuck, the third Dragon King, created a National Assembly in 1953, which facilitated dialogue by serving as a forum where elders from different provinces could voice their ideas for a better Bhutan. The second phase of democratisation began through Jigme Dorji Wangchuck's successor and son, Jigme Singye Wangchuck, who became the fourth King of Bhutan when he was only 17 years old. He ruled from 1972 until 2006, and his reign was marked by a benevolent and strong political and legal reform ${ }^{[1]}$. In fact, this monarch is perceived as the idealiser and proponent of democracy in Bhutan, and defended it based on Bhutan being a tiny and landlocked nation, with a small population, which, according to him, made it too risky for Bhutan to rely exclusively on one single individual. Jigme Singye Wangchuck also started the process of power devolution, by giving back administrative powers to the 20 districts of the country in the 1980s. Finally, the fourth King of Bhutan was also responsible for writing a draft Constitution - which would serve as a basis for the first Constitution of Bhutan, later ratified in 2008 -, which included articles that permitted royal impeachment if needed be, and mandated that the King must abdicate by the age of 65. In December 2005, Jigme Singye Wangchuck surprised everyone by announcing his intention to abdicate the throne by 2008, at the age of 52, which effectively meant that even at the peak of his popularity, Jigme Singye Wangchuck had decided he would hand over responsibilities to his son from that moment onwards. Astonishingly, the fourth Dragon King abdicated in the following year (2006), at the age of 50. And so began the third phase of democratisation. Jigme Khesar Namgyel Wangchuck, an Oxford graduate, became the fifth and current King of Bhutan, and soon followed his father's footsteps. The monarch's first mission was to proclaim an official transition to democracy, by making sure that

1. Curiously enough, it was Bhutan's fourth King, Jigme Singye Wangchuck, who coined the enticing concept of "Gross National Happiness" (GNH), which considers happiness as a measure of development within a nation. Bhutan, widely unknown until then, eventually took center stage because of such concept. GNH purposely came about as an antagonistic measure to the more globalised and monetary-focused GDP. 
the Bhutanese people were aware of the importance of democratic practices at all societal spheres, and that they knew how to deal with the institutional and bureaucratic procedures involved in the upcoming democratisation process. The King also needed to achieve two essential goals that would allow Bhutan to be perceived by the international community as a democracy: the enactment of a Constitution, and the implementation of free, nationwide elections. Jigme Khesar Namgyel Wangchuck then established a bicameral parliament, with an upper House, entitled National Council, with 25 elected members, and a lower house, the National Assembly (which had been created by his father), consisting of 47 elected partisan members. In order to be a candidate to both houses of the Parliament, a Bhutanese citizen needs to have a graduation degree, "a highly restrictive condition in a country with a literacy rate of no more than 60 percent and a narrow educational base" (Muni, 2014, p. 160).

Of course, such demand could be an incentive for future leaders to pursue higher education, although this could be seen as a rather optimistic and naïve assumption. Bhutan had its first elections on March 24, 2008, in which citizens voted at the national-parliamentary level, to choose members of parliament and a Prime Minis$\operatorname{ter}^{[2]}$, as well as at the local-municipality level. Two major parties eventually came to dominate the electoral process of democracy in Bhutan. From 2008 to the present day, the two dominant parties - the Bhutan Peace and Prosperity Party (DPT) and the People's Democratic Party (PDP) - have taken turns in leading the country. In 2008, when the first elections took place, the DPT won a mesmerising 45 of the 47 seats of the National Assembly, and its leader - Jigme Thinley - eventually became Prime Minister. The second electoral period was held in 2013. The PDP, which only had 2 seats at the National Assembly on the 2008 elections, attained majority in 2013, winning 32 seats out of the 47. Its leader, Tshering Tobgay, a Harvard graduate, is the current Prime Minister. New elections will take place in 2018. In 2008, the fifth Dragon King Jigme Khesar Namgyel Wangchuck also succeeded in enacting the first Bhutanese Constitution. The Bhutanese Constitution holds 34 articles, and guarantees fundamental rights to the people. The document also legitimises the King and the monarchical system, but given all the advances towards democracy that came from the King himself,

[i]t is therefore natural that the constitution, intended to bring in modern institutions to the country's polity, has not diminished the role of King, the agent of modernisation, even though executive powers have been entrusted to the elected government (Masaki, 2013, p. 61).

In any case, Kings are not necessarily protected from popular will:

(...) Article 2.26 provides for the possibility of abolishing the monarchy and changing the form of government by a national referendum. Also, the King still remains accountable to the parliament, which can pass a vote of no-confidence by a two-thirds majority (Gallenkamp, 2010, p. 12).

2. The Prime Minister, alongside a Council of Ministers, is responsible for the executive power in Bhutan. 
The drafting of a final version of the Constitution ${ }^{[3]}$ relied on public consultation with local peoples from all districts, whereby representatives of every household in Bhutan constituted local assemblies and deliberated alongside the King.

\section{Bhutan's Non-Linear Transition}

Bhutanese democracy currently stands as what is known as a hybrid regime - what Schmitter (1996a) considers as those that stand as an alternative to regressing to autocracy and progressing to democracy -, also known as "partial" or "illiberal" democracies. Of course, there are many examples of hybrid regimes around the world, but the version of democracy present in Bhutan defies conventional assumptions on democratic transition.

\subsection{The Process of Democratisation}

Let us consider several Freedom House Reports, particularly from 2003, which was when a transition to democracy de facto began. The 2003 Report on Bhutan hinted that the monarchy had become slightly more accountable to the people, through the drafting of a constitution and the occurrence of various debates at the National Assembly. Before that period, reports provided by Freedom House rarely mention any kind of democratic feature in Bhutan, or in fact any substantial sign of a democratisation process. From 2003 to 2006, the reports suffer slight changes, adding one sentence or another, but nothing too considerable. However, the 2007 report mentions the decision of the fourth King Jigme Singye Wangchuck to abdicate and to transfer his power to his son in 2008. From then on, both the reports and the scores seem to reveal positive outcomes. For instance, from 2003 to 2008, the scores credited by Freedom House remain unaltered: Bhutan ranks as Not Free, with a "Freedom Rating" of 5.5 ( 1 = best, 7 = worst) " "Civil Liberties" with the score of $5(1=$ best, $7=$ worst), and "Political Rights" attaining a 6 ( 1 = best, 7 = worst). It is only in 2009 that Freedom House acknowledges that Bhutan has "completed its transition from absolute to constitutional monarchy", which in turn altered its status from a Not Free to a Partly Free nation. In terms of scores, two of them improved in relation to previous years: "Freedom Rating" at 4.5 ( 1 = best, $7=$ worst), "Civil Liberties" with the score of 5 ( 1 = best, $7=$ worst $)$ - the one that did not alter -, and "Political Rights" at 4 ( 1 = best, 7 = worst). From 2010 to 2013, with the exception of a few occurrences (allegedly free local elections, for instance), the process of democratisation seemed to stall. Yet, in 2014, Freedom House upped all the scores of Bhutan: "Freedom Rating" at 3.5 ( 1 = best, 7 = worst), "Civil Liberties" with the score of $4(1=$ best, $7=$ worst $)$ - which had not been altered since 2003 -, and "Political Rights" at 3 ( $1=$ best, 7 = worst). These are the same values as the last report of 2016. According to Freedom House:

3. For a comprehensive analysis of the Bhutanese Constitution, see Gallenkamp (2010). 
Bhutan's political rights rating improved from 4 to 3 due to an increase in government transparency and a peaceful transfer of power after the opposition won parliamentary elections for the first time, and its civil liberties rating improved from 5 to 4 due to an increase in open and critical political speech, the political opposition's greater ability to hold demonstrations, and the growing independence of the judiciary (Freedom House Report on Bhu$\tan , 2016)$.

This growth is undoubtedly remarkable, and should be celebrated, especially if taking into account that only 10 years prior Bhutan epitomised a noticeably different scenario.

\subsection{Democracy by Royal Demand}

What is truly distinguishable about Bhutan's transition to democracy is the fact that the process of power decentralisation started precisely from the autocratic source of power, effectively making it a democracy by royal decree. This is a rare case where elites, rather than the people, push for democracy. That constitutes a shift on the usual paradigm of democratisation, where absolute monarchs usually oppose change, and as a result are overthrown and displaced. This might have an explanation based upon cultural precepts: as in most Asian societies, there is a widespread feeling of strong reverence and appreciation to leaders - in fact, the figure of the Dragon King is revered with utmost admiration. Historically speaking, Bhutanese people are used to a paternalistic political system, to what Sinpeng (2007) believes is due to Bhutan's "uneducated and politically docile population" (p. 40). Similarly, the people interpreted this paternalist inception of democracy as a "gift" from a concerned father to his children; and refusing a gift from the King would be completely unacceptable ${ }^{[4]}$. Moreover, the legitimisation of democracy in Bhutan occurred precisely because it came directly from the King, since the populace remained satisfied with the monarchical regime in place. The former Prime Minister of Bhutan, Jigme Thinley, told in an interview that Bhutanese citizens were initially apprehensive of democracy because of the poor democratic record in the South Asian region. According to the former Prime Minister:

(...) they were anxious. But the king prevailed over them, saying that even though the final choice must be theirs, they must realize that the king becomes the leader only by the accident of birth and not by merit or by virtue, and that to place the future of a country in the hands of such a person is not in the long-term interest of the country (Bhutan's Road to Democracy- Interview to the Prime Minister of Bhutan).

However, there are several opposing views to this claim. Phuntsho (2008) mentions that:

4. The concept of cognitive dissonance might be adequate for what Bhutanese citizens felt and might still feel in relation to democracy. 
Bhutanese were not spoon-fed with an unwanted democracy, let alone forcefed (...). Rather, Bhutanese took an active part in the process with enthusiasm and vigour. Villagers walked for hours from isolated areas to listen to the political candidates, who traversed the country campaigning for support. Thousands volunteered to work for the party of their liking and contributed huge amounts towards party funds. Politics became the topic of almost every conversation and the atmosphere was rife with political fervor and fear, speculation and gossip, and even exchanges of vitriolic allegation and mudslinging in the months leading up to the election. Democracy was taken up with such passion and earnestness that in some places friends and family were divided along political lines while elsewhere enemies have united under one political party.

Muni (2014) also argues that Bhutan does not stand as a case of "selfless enlightenment". Rather,

the monarchy is best understood as acting prudently in reaction to pressures emanating both from Bhutanese society and from a demanding regional environment dominated by the two huge neighbors that completely surround tiny Bhutan: China and India (p. 159).

Sinpeng (2007) is another author who sustains that the top-down decision to change to democracy was a decision based upon the inevitability of democracy:

The monarchy understands the peril of a tyranny and does not want to maintain the single-ruler system, despite its astounding success in consolidating a once fragmented nation and restoring peace and prosperity to the people. That is why King Wangchuck gave up his throne at the height of his power, while there is peace and prosperity within the country. In essence, King Wangchuck's decision to transition to democracy is a 'pre-emptive' one, under the assumption that such regime change is inevitable in the future and it is better to make a peaceful and orderly transformation rather than a violent one (p. 39).

Last but not least, Huntington (1991) says that some leaders realise the inevitability of democracy and prefer to concede partial defeat, inasmuch as it further legitimises the dictatorial regime:

The East European example had its principal effect on the leaders of authoritarian regimes, not on the people they ruled. President Mobutu Sese Seko of Zaire, for instance reacted with shocked horror to televised pictures of the execution by firing squad of his friend, Romanian dictator Nicolae Ceauşescu. A few months later, commenting that 'You know what's happening across the world', he announced that he would allow two parties besides his own to compete in elections in 1993 (p. 16).

Regardless of these claims, for what concerns the viewpoint presented in this paper, demanding democracy and participating in a democratic election are two disparate processes. The overwhelming majority of works and examinations of the Bhutanese case argue that the King's influence was nevertheless primordial in spreading a 
democratic spirit. Combined with the very nature of its political, social and religious philosophy, which prioritises the community over the individual, and giving a voice to every individual while encouraging one to express his or her views - something hitherto alien to Bhutanese citizens - it should be no surprise that the people must have been quite apprehensive with democracy to start with.

\subsection{Limited Democracy}

Bhutan stands as a case that somewhat defies Samuel Huntington's arguments on his The Third Wave of Democracy, particularly on his assertion that Confucian societies are rather antagonistic to democracy. Schmitter (1996b) says that

[f]or democracy to thrive (...) procedural norms must be followed and civic rights must be respected. Any polity that fails to impose such restrictions upon itself, that fails to follow the 'rule of law' with regard to its own procedures, should not be considered democratic (pp. 54, 55).

At the same time, the author considers some intrinsic procedures that make democracy possible. Hence, if in fact we do consider that there ought to be basic principles and premises for a democracy to exist (i.e. free elections and a parliamentary system), then it is clear that Bhutan has succeeded in meeting them. Accordingly, Diamond (1995) asserts that

(...) [t]he single most important and urgent factor in the consolidation of democracy is (...) political institutionalization (p. 238).

In other words, since Bhutan has met both mentioned conditions that usually make democracy possible, then Bhutan has surely delivered. This should prove that, contrary to what Huntington believed, democracy can be deepened without the need to follow a Western pattern. Nevertheless, this raises a potential weakness of Bhutanese democracy: that in order to be considered a democracy, one must solely rely on a procedural, institutional, and Schumpeterian-like version of democracy - which establishes that a regime is democratic if holding parliamentary politics, electoral processes, an adopted constitution and democratic institutions in place. In effect, Bhutan holds a democracy with limitations. Whilst democratic institutions might be all in place and working properly in Bhutanese lands, a deeper democratic spirit might be constrained by the lack of liberty still existent in there, something that Western liberal democracy otherwise provides.

\subsection{Cultural Preservation}

Political reform in Bhutan has also led to some modernisation, which in turn might lead a given country to some cultural disintegration in favour of social pluralism. For Bhutan, however, cultural preservation is of utmost importance. Both political and economic development have not endangered the cultural traditions of the country or its environment. As an illustration, Gallenkamp (2010) mentions that: 
Due to Bhutan's [intentional] isolation, all major political currents sweeping the world in the first half of the twentieth century, whether capitalism, socialism, communism, or liberalism, had no impact on the Bhutanese polity and political culture (p. 6).

Likewise, in the late 1980s, given the existence of several ethnic groups with Nepalese origin in the southern part of the country, Bhutan established a "One People, One Nation" motto, which materialised in a series of policies that aimed at guaranteeing the homogeneity of Bhutanese culture. One of those was a policy that obliged citizens to dress according to the ruling Ngalong Drukpa ethnic group, which was primarily located in the Northern region of Bhutan ${ }^{[5]}$. Such action was justified by authorities as a "fear for the survival of Drukpa culture because of the large number of Nepali speakers, also known as Southern Bhutanese (...)” (Freedom House Report on Bhutan, 2003).

This particular policy eventually led to a dramatic expulsion of thousands of people: over one-hundred thousand Nepalese refugees (called Lhotshampa) were expelled and flown out of Bhutan in the 1990s, and to this day "live in crowded camps inside Nepal (...). Exiled groups say tens of thousands have been denied identity cards - and thus voting rights" (Ramesh, 2008).

It is clear that such obsessive preoccupation of Bhutanese officials (and eventually of the majority of citizens) to protect their identity and culture is contrary to what Western democratic principles mandate, such as equality, pluralism, tolerance for other faiths and beliefs, and respect for cultural diversity.

\subsection{Secularism and Democracy}

Buddhism and its moral and practical preambles are deeply enshrined within Bhutanese society. Taking into account that Asian and Buddhist philosophies emphasise social and personal harmony, it should not come as a surprise that the Bhutanese transition to democracy has been a fairly methodical, well-ordered and pacific one. Consequently, the Bhutanese government still subsidises Buddhist monasteries, temples, and shrines, while monks - who are widely respected - do have political influence $^{[6]}$. This is where Bhutan's version of democracy is distinguishably different from liberal one. Liberal democracies perceive secularism as an important pillar of social cohesion, for without it religious conflicts endlessly emerge, and democratic consolidation becomes virtually impossible. At the same time, a contradictory and even paradoxical fact is that the legal constitutional framework of Bhutan actually guarantees freedom of religion, but the act of proselytism is forbidden by royal decree. It becomes clear that the biggest obstacle to consolidation is Bhutan's disposition towards religious freedom. In other words, it is not the fact that religious freedom does not exist in theory; the problem is that the morals of Buddhism are so enshrined

5. See Freedom House Report on Bhutan 2003.

6. See Freedom House Report on Bhutan 2003. 
within the people and onto every sphere of social and political life that it actually becomes unthinkable to consider other religions. As a result, Bhutanese society, purposely or unconsciously, discourages and condemns religious freedom.

\section{Concluding Remarks}

Bhutan stands as a rather unique case of a transition to a democratic regime - a democracy by obligation. If so, it is clear that there is not a common pattern to the transition to democratic regimes, and that we rather witness a political "gray zone" in the transition process towards democracy. In any case, what should be clear is that contrary to what Samuel Huntington conveys on his Third Wave of Democratization, democracy and democratisation are not simple procedural models that merely require a simplistic, one-dimensional, straightforward implementation. The very concept of democracy is equally disputable - or otherwise all democrats would interpret it in the same way.

Bhutan, with its overwhelmingly peaceful landscapes that resemble it social and political progress, still has a long way to go. In many ways, its stern avoidance on opening-up to the rest of the world, and its concomitant efforts in resisting globalisation, while enabling its centurial culture to remain significantly preserved, have affected its process of social, political and economic development. Nevertheless, since welcoming democracy "from above", Bhutan has experienced an astounding progress. Each year, this country seems to move up the ladder towards a more consolidated and sizeable democracy. What is also obvious is that when a nation welcomes democracy it must be aware that it entails a change of not just procedures, but more importantly, of ways of life. Bhutan needs to interpret the concept of democracy as not only a procedural tool, but also as an organic and multidimensional notion. Arguably, embracing the latter is to concede to a liberal version of democracy, which might not be desirable by Bhutanese officials. This is the greatest barrier for Bhutan, which usually entails a long-lasting psychosocial transformation. If a democratic spirit is given enough time to sprout, citizens gradually become empowered, hence reducing the political influence of the King - something that various Dragon Kings have welcomed. This is undoubtedly Bhutan's major advantage, for the benevolent monarchs have been as sympathetic with the democratic cause as the people ought to be.

\section{References}

Bertelsmann Stifung (BTI 2014). Bhutan Country Report. Gütersloh, Germany: Bertelsmann Stifung.

Bertelsmann Stifung (BTI 2016). Bhutan Country Report. Gütersloh, Germany: Bertelsmann Stifung.

Bhutan's Road to Democracy - Interview to the Prime Minister of Bhutan. Council on Foreign Relations. Retrieved from: <http://www.cfr.org/bhutan/bhutans-road-democracy/ p17331> [accessed 30 ${ }^{\text {th }}$ September 2017]. 
Bhutan Final Report - National Assembly Elections. European Union Election Observation Unit. Retrieved from: <http://www.eods.eu/library/eu_eom_bhutan_2008_final_report.pdf $>$ [accessed 29 ${ }^{\text {th }}$ September 2017].

Country Strategy Paper Bhutan 2007-2013. European Union External Action. Retrieved from: $<$ http://eeas.europa.eu/bhutan/csp/07_13_en.pdf> [accessed $1^{\text {th }}$ October 2017].

Diamond, L. (1995). Toward Democratic Consolidation. In L. Diamond \& M. Plattner (Eds.), Economic Reform and Democracy (1st ed.). Baltimore: Johns Hopkins University Press.

Diamond, L. (2002). Thinking About Hybrid Regimes. Journal of Democracy, 13(2), 21-35. Retrieved from: <http://www.asu.edu/courses/pos350/diamond--Thinking\%20about\%20 Hybrid\%20Regimes.pdf> [accessed $1^{\text {st }}$ October 2017].

Freedom House Report on Bhutan (2003). Retrieved from: <https://freedomhouse.org/report/ freedom-world/2003/bhutan $>$ [accessed 27th September 2017].

Freedom House Report on Bhutan (2009). Retrieved from: <https://freedomhouse.org/report/ freedom-world/2009/bhutan $>$ [accessed 27 th September 2017].

Freedom House Report on Bhutan (2014). Retrieved from: <https://freedomhouse.org/report/ freedom-world/2014/bhutan $>$ [accessed 27th September 2017].

Freedom House Report on Bhutan (2016). Retrieved from: <https://freedomhouse.org/report/ freedom-world/2016/bhutan $>$ [accessed 27 th September 2017].

Gallenkamp, M. (2010). Democracy in Bhutan An Analysis of Constitucional Change in a Buddhist Monarchy. IPCS Research Papers. Retrieved from: <http://www.ipcs.org/pdf_file/ issue/RP24-Marian-Bhutan.pdf> [accessed 29 $9^{\text {th }}$ September 2017].

Huntington, S. (1991). The Third Wave of Democratization. Journal of Democracy, 2(2), 12-34.

Kaul, N. (2008, March 27). Bhutan is neither authoritarian nor stuck in a time warp. The Guardian. Retrieved from <https://www.theguardian.com/commentisfree/2008/mar/27/1> [acedido a 28.09.2017].

Masaki, K. (2013). Exploring Bhutan's 'Natural Democracy': In Search of an Alternative View of Democracy. Journal of Bhutan Studies, 28, 47-72.

Muni, S. D. (2014). Bhutan's Deferential Democracy. Journal of Democracy, 25(2), 158-163.

Phuntsho, K. (2008). Bhutan's unique democracy: a first verdict. openDemocracy. Retrieved from <https://www.opendemocracy.net/article/institutions/bhutan_s_unique_democracy_a_first_verdict> [acedido a 29.09.2017].

Ramesh, R. (2008, March 25). Voters flock to Gross National Happiness. The Guardian. Retrieved from <https:/www.theguardian.com/world/2008/mar/25/1> [acedido a 28.09.2017].

Sinpeng, A. (2007). Democracy from Above: Regime Transition in the Kingdom of Bhutan. Journal of Bhutan Studies, 17, 21-47.

Schmitter, P. C. (1996a). Dangers and Dilemmas of Democracy. In L. Diamond \& M. Plattner (Eds.) The Global Resurgence of Democracy (2nd ed.). Baltimore \& London: Johns Hopkins University Press.

Schmitter, P. C. (1996b). What Democracy Is and Is Not. In L. Diamond \& M. Plattner (Eds.) The Global Resurgence of Democracy (2 ${ }^{\text {nd }}$ ed.). Baltimore \& London: Johns Hopkins University Press. 
Sinpeng, A. (2007). Democracy from Above: Regime Transition in the Kingdom of Bhutan. Journal of Bhutan Studies, 17, 21-47.

The Constitution of the Kingdom of Bhutan. Retrieved from: <http://www.bhutanaudit.gov.bt/ About\%20Us/Mandates/Constitution\%20of\%20Bhutan\%202008.pdf> [accessed $28^{\text {th }}$ September 2017].

The World Factbook - Bhutan. Central Intelligence Agency. Retrieved from: <https://www.cia. gov/library/publications/the-world-factbook/geos/print_bt.html $>$ [accessed 2 ${ }^{\text {nd }}$ October 2017].

Tourism Council of Bhutan - Society. Retrieved from: <http://www.tourism.gov.bt/about-bhu$\tan /$ society $>$ [accessed 30 ${ }^{\text {th }}$ September 2017].

Tourism Council of Bhutan - Political System of Bhutan. Retrieved from: <http://www.tourism.gov.bt/about-bhutan/political-system-of-bhutan> [accessed $30^{\text {th }}$ September 2017].

Turner, M, Chuki, S. \& Tshering, J. (2011). Democratization by decree: the case of Bhutan. Democratization, 18(1), 184-210. Retrieved from: <http://www.rim.edu.bt/10/wp-content/uploads/2013/07/TURNER-DEMOCRATIZATION-BY-DECREE.pdf> [accessed $1^{\text {st }}$ October 2017].

\section{Sobre o autor}

KARIM QUintino é licenciado em Ciência Política pela Universidade de Westminster, mestre em Teoria Política pela LSE - London School of Economics and Political Science, doutorando em Ciência Política e Relações Internacionais pelo Instituto de Estudos Políticos da Universidade Católica Portuguesa e Visiting Student na Univeridade de Oxford. Foi professor auxiliar e investigador na Universidade de Westminster e também professor, coordenador pedagógico e diretor-geral de diversos estabelecimentos escolares em Portugal e no Brasil. Atualmente, é investigador do CIEP - Centro de Investigação do Instituto de Estudos Políticos da Universidade Católica, assessor parlamentar na Assembleia da República e tradutor.

\footnotetext{
About the author

KARIM QUINTINO holds a bachelor's degree in Political Science from the University of Westminster, and a master's in Political Theory from LSE-London School of Economics and Political Science. He is a PhD student in Political Science and International Relations at Institute for Political Studies of the Universidade Católica Portuguesa, and Visiting Student at the University of Oxford. He was assistant professor and researcher at the University of Westminster and also professor, educational coordinator and general director of several schools in Portugal and Brazil. Currently, he is researcher of the CIEP-Research Center of the Institute for Political Studies of the Universidade Católica, parliamentary advisor to the Assembly of the Republic and translator.
} 